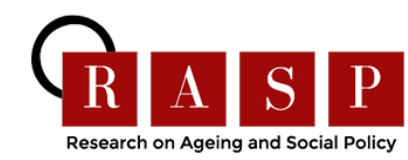

Instructions for authors, subscriptions and further details:

http://rasp.hipatiapress.com

\title{
Aging, Marital Status, and Loneliness: Multilevel Analyses of 30 Countries ${ }^{1}$
}

Elyakim Kislev

The Hebrew University

Date of publication: January $30^{\text {th }}, 2022$

Edition period: January 2022 - July 2022

To cite this article: Kislev, E. (2022). Aging, Marital Status, and Loneliness: Multilevel Analyses of 30 Countries Research on Ageing and Social Policy, 10(1), 77-103. http://dx.doi.org/10.17583/rasp.2022.8923

To link this article: http://dx.doi.org/10.17583/rasp.8923

\section{PLEASE SCROLL DOWN FOR ARTICLE}

The terms and conditions of use are related to the Open Journal System and to Creative Commons Attribution License (CCAL). 


\section{Aging, Marital Status, and Loneliness: Multilevel Analyses of 30 Countries ${ }^{1}$}

Elyakim Kislev

The Hebrew University

\section{Abstract}

Using the European Social Survey and the UN databases, this paper investigates the differences in feelings of loneliness among different marital status groups in old age. Findings presented in this paper suggest that married elders are the least lonely group, while never-married elders come thereafter, better than widowed, divorced, and separated elders. Overall, while married individuals are the happiest and the least lonely of all groups, marriage, on average, ends up with less benign results in late stages of life. The discussion part in this paper suggests that these findings might fit with the "greedy marriage" argument that long-term nevermarried people develop social skills and circles over time, which allows them to be more immune to loneliness and depression than widowed, divorced, and separated elders.

Keywords: aging; marriage; divorce; singlehood; loneliness 


\section{Envejecimiento, Estado Civil y Soledad: Análisis Multinivel de 30 Países $^{1}$}

Elyakim Kislev

The Hebrew University

\section{Resumen}

Utilizando la Encuesta Social Europea y las bases de datos de la ONU, este trabajo investiga las diferencias en los sentimientos de soledad entre los distintos grupos de estado civil en la vejez. Los resultados presentados en este trabajo sugieren que los ancianos casados son el grupo menos solitario, mientras que los que nunca se han casado vienen después, mejor que los viudos, divorciados y separados. En general, mientras que los individuos casados son los más felices y los menos solitarios de todos los grupos, el matrimonio, por término medio, termina con resultados menos benignos en las últimas etapas de la vida. La parte de la discusión de este artículo sugiere que estos resultados podrían encajar con el argumento del "matrimonio codicioso", según el cual las personas nunca casadas a largo plazo desarrollan habilidades y círculos sociales con el tiempo, lo que les permite ser más inmunes a la soledad y la depresión que los ancianos viudos, divorciados y separados.

Palabras clave: matrimonio; divorcio; soltería; soledad 
inglehood in old age is increasingly observed in many countries across the world. As the number of years we are living increases, so does the potential amount of time that an individual can live alone, whether this is due to the increased length of an average widowhood (Eng, 1997) or as a result of the fact that never-married or divorced individuals live for longer, resulting in more adults being single for longer periods of time (Bengtson \& Putney, 2000; Cheung \& Yeung, 2015; Golini \& Silverstrini, 2013; Vitali, 2010). Data from the Survey of Health, Ageing and Retirement in Europe (SHARE), for example, indicate that among Europeans, aged 75 and older, 57 percent were widowed in 2015 (Börsch-Supan, 2018). Moreover, in developing countries, where the life expectancy is increasing most rapidly, the number of older people is expected to inflate the number of singles most drastically (Cheung \& Yeung, 2015).

Besides the effect of an increasing life expectancy, many choose to stay single. In the United States for example, approximately one-quarter of newborns are predicted to never marry (Wang \& Parker, 2014). In Europe, more than $50 \%$ of addresses in big cities such as Munich, Frankfurt and Paris are single-occupant homes (Euromonitor, 2013). If current numbers hold, even those who will marry will face over 40 percent chance of divorce, after which 70-80 percent of divorcees will remarry and face a second divorce (Cherlin, 2009). Therefore, singlehood rates are expected to rise significantly in the foreseeable future.

Loneliness in old age is oftentimes linked to singlehood. One main reason for this is the decline in mental and physical health and the challenge in coping with these difficulties alone. Deteriorated mental health in old age includes problems such as mental disorders, inability to deal with life's problems effectively, cognitive misevaluation of life, reduced wellbeing, and social dysfunction (Gatz \& Zarit, 1999; Halmos, 2013; Post, 1951). Older adults also report poorer physical health than younger adults and mobility issues (Sargent-Cox et al., 2010). These conditions make older people feel they need someone to help them and spouses are those who are expected to help in these situations (Victor et al., 2000; Walsh, 1996). Moreover, declines in physical health and mobility lead to staying at home more, as well as to increased embarrassment from being seen by others (Lawton \& Lawrence, 1994). In this sense, married partners are those who stay at home and are sometimes the sole 
companion of older adults in need.

Such real or expected needs, when left unanswered, are likely to increase feelings of loneliness (Kay et al., 1964). In turn, loneliness is increasingly viewed as a major concern (John et al., 2017; Pinquart \& Sörensen, 2003) because it is oftentimes the source of secondary problems such as anxiety, depression, and other physical and mental health problems, including cardiovascular disease (Sorkin et al., 2002) and the onset of dementia (Holwerda et al., 2012). In particular, loneliness has been found as the main problem in referrals of older people to social services and significantly correlates with entry to residential care (Wenger, 1992).

The question to be tested empirically in this current study, however, is whether being married actually helps singles in old age. This paper investigates the differences in loneliness among single, married, widowed, and divorced persons in old age using the European Social Survey in multilevel analyses, cross-sectionally. While longitudinal analyses is many times preferable in studying aging process, the statistical power of the European Social Survey together with the ability to account for cross-country differences in hierarchical structure is invaluable here.

\section{Loneliness in Old Age}

To understand the meaning of loneliness for older people, It is important to define the term loneliness first. Loneliness is "a discrepancy between one's desired and achieved levels of social relations" (Perlman \& Peplau, 1981), where this discrepancy may concern the number of relationships or the intimacy of the relationships available (Fokkema et al., 2012). According to Weiss (1973), loneliness has social and emotional dimensions. Social loneliness refers to the absence of a wider circle of friends and acquaintances that provide a sense of belonging, companionship, and being a member of a community. Correlates of social loneliness among older people may include, for instance, reduced social activities (Newall et al., 2009) and a lack of connection with ones' own neighborhood (Scharf et al., 2005). Emotional loneliness refers to the absence of an attachment figure in one's life and someone to turn to (Drennan et al., 2008; Dykstra \& Fokkema, 2007).

This distinction is particularly relevant for older singles as it shows that the reasons for loneliness vary and that partnership is not necessarily the answer. Sometimes social loneliness is what matters and this can actually stem from 
having a partner rather than not having one (Aartsen \& Jylhä, 2011; Dahlberg $\&$ McKee, 2014). Indeed, studies show that turning inwards toward the family for many years might entail feeling socially isolated in older age (Einolf \& Philbrick, 2014; Gerstel \& Sarkisian, 2006). In addition, married couples in later life can also be susceptible to emotional or social loneliness as a result of a poor quality of marriage (de Jong Gierveld et al., 2009). Therefore, it is an empirical question how loneliness is perceived among married and unmarried older people.

\section{Loneliness in Old Age and Marital Status}

Proponents of marriage argue that living as a couple or as a family helps to prevent situations of loneliness (e.g. Waite \& Gallagher, 2000; Stack, 1998). However, while a successful marriage where both partners are healthy can reasonably be expected to prevent loneliness and promote wellbeing in later years, an unhappy marriage or low appraisal of married life can result in increased feelings of loneliness, as previous studies show (e.g. Ayalon et al., 2013).

In addition, although there is a widespread belief that being married is a safety net for distressed times over life course, this notion has been contested (Morris et al., 2007). The argument is that while marriage is assumed to provide assistance, longitudinal studies show how having a disability, for example, relates to being abandoned in larger numbers (McKenzie, 2013; Powdthavee, 2009; Singleton, 2012). Another study shows that the probability of divorce over life course increases following a spouse's job displacement (Brand, 2015). Instead of being supported, many spouses find themselves in extremely stressful situations that soon end their marriages. Presumably, job loss skews income expectations which, in turn, change anticipated gains from marriage and make the partner less "worthy", as cruel as it may sound (Charles \& Stephens, 2004).

Finally, not only that the disabled or unemployed persons are more likely to be divorced, but even if they remain married, the burden falls solely on their partners as relationships with people in outer circles weaken. Gerstel and Sarkisian (2006) explain that the traditional family unit, with its high expectations of support, can cause individuals to turn inward toward their nuclear family unit and away from resources in outer circles, a phenomenon 
named in their research as "greedy marriage". Thus, even if the couple stays married, the burden becomes more difficult to carry after the surrounding social resources dry up over the years. Meanwhile long-term singles spend years growing their networks, developing their social capital skills, engaging in leisure, and raising self-confidence outside of the framework of marriage (DePaulo, 2007).

Therefore, the current study set out to address the question whether there are differences in loneliness levels between married, divorced, widowed, and never-married older individuals and the magnitude of these differences.

\section{Marital Status and Loneliness in Old Age: Mediating Mechanisms}

In considering the effect of marital status on older singles, some potential intervening factors should be incorporated in the analyses below, which are unique to this situation (apart from health, income, etc.). The first factor incorporated is social capital which is divided to social meetings (e.g. meeting with friends and relatives) and social activities (e.g. participating in local clubs) (Kislev, 2019b). Involvement with friends and social networks can give the feeling of support and not 'missing out' (Gerstel \& Sarkisian, 2006). In addition to investing in friends, community-based services are much more critical and effective in abating the feelings of loneliness and reducing the negative effects of the particular challenges facing older singles. Indeed, studies show that older singles, and in particular women, are the most likely to benefit from community centers activities and services, and as such, expand their social networks the most easily (Aday et al., 2006). Moreover, previous research shows that such services are particularly impactful for older singles who are childless, live far away from any children, and are members of a minority group (Weis Farone et al., 2005).

The second factor is religiosity. Many religions place high importance on familial and traditional values. Extra-marital sex is viewed negatively, preferring late marriage over single or unmarried parenthood (Lavee \& Katz, 2003) and divorce is discouraged if not prohibited (Kunz \& Albrecht, 1977). Conversely, non-religious individuals are more accurately characterized by openness to singles and a widespread movement away from religious values that form the basis of the family institute, possibly explaining the relatively higher levels of never-married individuals among them (Wilson, 2002). The counter argument, however, is that being religious provides unmarried elders 
some support, mentally, physically, and even socially (Ardelt, 2003). Therefore, this variable is an intervening mechanism with an unknown effect that should be tested here empirically.

Evidence also suggests that the extra discrimination, prejudice, and societal expectations placed on and against single women negatively impact them in various aspects of life. This includes academic motivation (Meece et al., 2006), career development (Fischlmayr, 2002), participation in business and entrepreneurship (Wilson et al., 2007), and involvement in science, technology, and related fields (Zeldin et al., 2008). On the other side, divorced and widowed men are particularly susceptible to the pitfalls of greedy marriage, not least because they become less fiscally generous to their friends and relatives following marriage (DePaulo, 2007; Kislevb, 2020). This is especially remarkable since studies indicate that married men earn more than single men do (DePaulo, 2011). Nevertheless, married men invest less resources in their social circles and, therefore, they are more vulnerable and have less economic and emotional resources of support in times of need (DePaulo \& Morris, 2006; Kislev, 2018). Therefore, gender is expected to play a significant role in mediating the associations here, hence the analyses in this paper distinguish between men and women.

Further complicating the issue of whether marriage can help to decrease loneliness over life course is the issue of selection. A longitudinal study spanning 17 years found a strong self-selection effect, where happier singles were more likely to choose to get married in the first place (Stutzer \& Frey, 2006). If happier, or indeed, less lonely individuals are more likely to get married in the first place, it could be that the effects of marriage on loneliness over life course are more limited than previously estimated (see for example: Waite \& Gallagher, 2000). Additionally, other longitudinal studies show that marriage is only a transitory factor in increasing wellbeing and influences only around the wedding itself (Lucas et al., 2003). Specifically, Lucas and his team found that there is a temporary positive effect of marriage, but typically wellbeing levels revert two years after marriage to the same baseline level held before marriage. Some other studies show a slight lasting advantage for marriage (Clark et al., 2008; Zimmermann \& Easterlin, 2006). In any case, although the debate continues (Clark \& Georgellis, 2013; Frijters et al., 2011; Musick \& Bumpass, 2012; Soons et al., 2009), the phenomenon of diminishing returns from marriage over life course is especially relevant for 
older people. This is because most of them are far away from the transitory effect of the wedding. While the current study is cross-sectional, results from other studies regarding the selection effect are taken into account in the discussion section.

\section{Method and Data}

The data of this research comes from the 2006, 2010, 2012, and 2014 waves of the European Social Survey (ESS), where the variable of loneliness is available. Respondents are split according to marital status: married, widowed, divorced/separated, and never-married. Divorced and separated individuals are combined since no significant differences are found between the two categories, and the number of separated individuals is relatively small. Cohabiting older individuals are excluded from this study because the sample size is too low at this age cohort.

Since this paper investigates the loneliness of older people, data was extracted and separated for respondents over 65 and over 75 years old. Although many retire beforehand, 65 corresponds with a typical age of retirement, following which people are at risk of psychosocial changes that affect health, happiness, and loneliness (Rosenkoetter \& Garris, 1998). The over-75 category was chosen since by this age, the majority are widowed (Börsch-Supan, 2018), and almost all respondents would have experienced a significant period of retirement.

The data collected includes demographic and socioeconomic characteristics that according to available research mediate levels of loneliness: subjective view of health (measured on a 1-5 scale), years of schooling, subjective income (measured on a 1-4 scale), whether the respondent ever cohabited, religiosity (yes/no), and the degree of social meetings (measured on a 1-7 scale) and social activities (measured on a 1-5 scale).

In addition to these factors, the analyses account for countries of residency on a higher level with attributed mean levels of loneliness in each country (see Table 1). Thus, the characteristics of individuals and their countries are modelled by other, less observable, country factors such as cultural characteristics and tendencies in addressing subjective wellbeing questions. Furthermore, the country levels are decomposed by the country's Human Development Index (HDI, 2016) that provides a broad picture of a country's 
85 Aging, Marital Status, and Loneliness - Kislev

life expectancies, adult literacy rates, GDP, and gross enrolment ratios in primary, secondary, and tertiary education. Further, the 'year of survey' is being used to account for the concern that there are differences between different periods of time.

Table 1.

Degree of Loneliness by Country, Age 65 and above.

\begin{tabular}{|c|c|c|c|c|}
\hline \multirow[b]{2}{*}{ Variable } & \multicolumn{4}{|c|}{ Loneliness (1-4) } \\
\hline & $\begin{array}{l}\text { Never- } \\
\text { married }\end{array}$ & Married & $\begin{array}{l}\text { Divorced/ } \\
\text { Separated }\end{array}$ & Widowed \\
\hline Austria & 1.69 & 1.25 & 1.63 & 1.94 \\
\hline Belgium & 1.37 & 1.21 & 1.66 & 2.03 \\
\hline Bulgaria & 2.45 & 1.47 & 2.21 & 2.57 \\
\hline Croatia & 2.19 & 1.67 & 2.08 & 2.28 \\
\hline Cyprus & 2.18 & 1.48 & 2.67 & 2.34 \\
\hline Czech & 1.90 & 1.50 & 2.09 & 2.27 \\
\hline Denmark & 1.10 & 1.11 & 1.34 & 1.48 \\
\hline Estonia & 1.75 & 1.36 & 1.76 & 1.91 \\
\hline Finland & 1.46 & 1.18 & 1.51 & 1.66 \\
\hline France & 1.81 & 1.25 & 2.05 & 2.20 \\
\hline Germany & 1.44 & 1.15 & 1.42 & 1.77 \\
\hline Greece & 2.20 & 1.67 & 2.67 & 2.56 \\
\hline Hungary & 1.96 & 1.33 & 2.04 & 2.35 \\
\hline Iceland & 1.00 & 1.11 & 1.80 & 1.32 \\
\hline Ireland & 1.69 & 1.26 & 1.74 & 1.75 \\
\hline Israel & 1.84 & 1.38 & 1.78 & 2.12 \\
\hline Italy & 1.94 & 1.40 & 2.00 & 2.10 \\
\hline Lithuania & 2.14 & 1.51 & 1.98 & 2.21 \\
\hline Netherlands & 1.51 & 1.16 & 1.46 & 1.70 \\
\hline Norway & 1.37 & 1.13 & 1.40 & 1.57 \\
\hline Poland & 2.28 & 1.34 & 2.07 & 2.15 \\
\hline Portugal & 2.01 & 1.49 & 2.08 & 2.23 \\
\hline
\end{tabular}


RASP - Research on Ageing and Social Policy 10(1) 86

(continued)

Table 1.

Degree of Loneliness by Country, Age 65 and above (continued)

\begin{tabular}{ccccc}
\hline \multicolumn{5}{c}{ Loneliness (1-4) } \\
\hline Variable & $\begin{array}{c}\text { Never- } \\
\text { married }\end{array}$ & Married & $\begin{array}{c}\text { Divorced/ } \\
\text { Separated }\end{array}$ & Widowed \\
\hline Russia & 2.35 & 1.56 & 2.22 & 2.35 \\
Slovakia & 2.11 & 1.51 & 2.16 & 2.25 \\
Slovenia & 1.80 & 1.33 & 1.62 & 1.99 \\
Spain & 1.70 & 1.31 & 1.95 & 1.97 \\
Sweden & 1.63 & 1.15 & 1.55 & 1.78 \\
Switzerland & 1.43 & 1.14 & 1.40 & 1.62 \\
Ukraine & 2.79 & 1.70 & 2.43 & 2.63 \\
U. Kingdom & 1.44 & 1.19 & 1.59 & 1.76 \\
All & 1.73 & 1.31 & 1.76 & 2.09 \\
\hline
\end{tabular}

Source: Own elaboration on the European Social Surveys.

In measuring loneliness, data was taken from the answer to the question that asks how much of the time during the past week the respondents felt lonely, rated on a 1-4 scale. This indicator is based on previous studies on loneliness (Victor \& Yang, 2012; Yang \& Victor, 2011). Since the meanings of loneliness vary greatly and are difficult to measure in one survey question, this study uses a large sample from a wide variety of countries to account for variability. As such, this study assumes that, on aggregate, the questions of the European Social Survey are instructive enough.

All calculations are weighted with the weights provided by the ESS and properly applied only in the fixed-effect (lower) level. In addition, note that the results presented here closely resemble those yielded from fixed-effectonly models. Finally, given the very large sample, the analysis could produce statistical significance even for small point estimates. Thus, I also estimated the effect size. This is not an easy task since the equations are complex and multilevel. Therefore, I first estimated the parallel fixed-effect models, where the results closely resemble those yielded from the mixed-effect models, and based on this estimation, I calculated the Cohen's D measures. Indeed, the 
estimated effect size measures show that the results of this study are practically significant.

\section{Findings}

The first question to be answered is how marriage affects loneliness on average, for the never-married group versus the ever-married group (including when marriage ends in divorce, separation, or widowhood). The division by marital status will be analyzed subsequently. Thus, the following chart illustrates the results of two groups: the "ever married", those who marry at some point in life (some, of course, are still married), and the "never-married", those who did not marry. The y-axis is the degree respondents felt lonely in the week preceding the survey. The graph shows that over life course the correlation of being ever married with feeling lonely is decreasing; at the age of 78, it is "statistically better" to not be married in the first place. On average, picking the marriage path has negative consequences from this age onward.

Figure 1. Feeling Lonely by Age and Marital Status

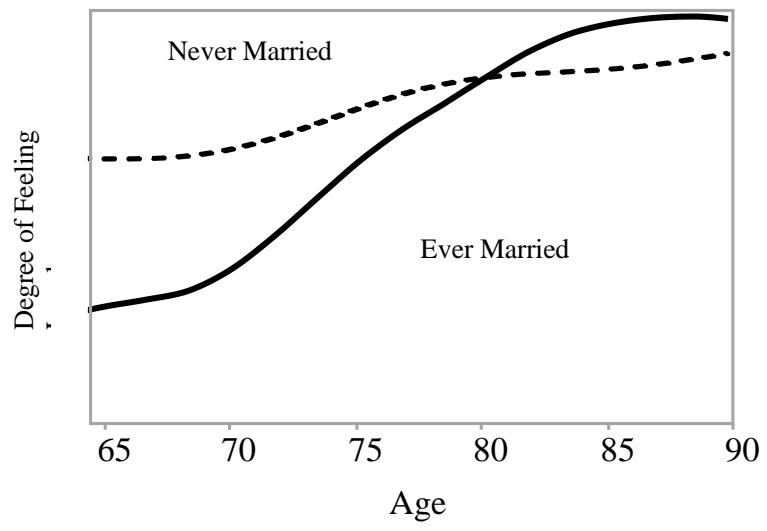

This finding is tested more accurately in the analysis presented in Table 2 , accounting for other factors such as health, income, education, social capital, and previous experience with cohabitation. The main term in this table is the interaction term between marital status and age. One can see how loneliness becomes more common among the ever-married group in 
comparison to the never-married group with increased age. With every additional year of age, those who are currently married or were married in the past feel lonelier, especially in the age-group of 75 and above.

Table 2.

Coefficients of Hierarchical Models of Loneliness in Old Age in Interaction with Age

\begin{tabular}{lll}
\hline Variable & $<65$ & $<75$ \\
\hline Individual Characteristics & & \\
Female & $0.159^{* * *}$ & $0.195^{* * *}$ \\
Subjective health & $-0.113^{* * *}$ & $-0.119^{* * *}$ \\
Years of schooling & $-0.005^{*}$ & $-0.005^{* *}$ \\
Subjective income & $-0.144^{* * *}$ & $-0.134^{* * *}$ \\
Never cohabit & $-0.237^{* * *}$ & $-0.231^{* * *}$ \\
Degree of religiosity & $0.006^{* *}$ & $0.008^{* *}$ \\
Social meetings & $-0.023^{* * *}$ & $-0.035^{* * *}$ \\
Social activities & $-0.079^{* * *}$ & $-0.095^{* * *}$ \\
Never married & $1.176^{* * *}$ & $1.475^{* * *}$ \\
Age & $0.012^{* * *}$ & $0.019 * * *$ \\
Never married*age & $-0.014 * * *$ & $-0.017^{* * *}$ \\
Country Characteristics & & \\
$\quad$ Mean of loneliness & $0.409^{* * *}$ & $0.506^{* * *}$ \\
$\quad$ HDI & 0.178 & 0.262 \\
Intercept & $0.869^{* *}$ & 0.139 \\
Variance Components & & \\
Country variance & $-3.412^{* * *}$ & $-3.619 * * *$ \\
Individual variance & $-0.273^{* * *}$ & $-0.211^{* * *}$ \\
$\mathrm{~N}$ & 36236 & 14818 \\
\hline
\end{tabular}

$* \mathrm{P}<.1 * * \mathrm{P}<.05 * * * \mathrm{P}<.01$

Source: Own elaboration on European Social Surveys (2006, 2010, 2012, and 2014 waves where the variable of loneliness is available).

Note: additional covariate included in model but not shown here is Year of Survey. 
89 Aging, Marital Status, and Loneliness - Kislev

\section{Accounting for Four Different Marital Statuses}

As shown in previous studies, what stands behind the findings so far is that divorcees and widowed individuals feel lonelier than both those who have never been married and those who are still married (Kislev, 2019a). This is particularly important for older people because the likelihood of being divorced or widowed rises with age (Kalmijn \& van Groenou, 2005; Lopata, 1969).

Therefore, to test the aforementioned results, four marital statuses are estimated separately - married, never-married, widowed, and divorced/separated - in relation to loneliness. This analysis accounts for various intervening factors such as education, income, health, religion, sociability, and country of residence. The outcomes are estimated for ages 65 and above and again, as a sensitivity analysis, for ages 75 and above.

Table 3.

Coefficients of Hierarchical Models of Loneliness in Old Age, by Age

\begin{tabular}{lll}
\hline Variable & $<65$ & $<75$ \\
\hline Individual Characteristics & & \\
Female & 0.001 & $-0.031^{*}$ \\
Age & -0.024 & 0.033 \\
Age squared & 0 & 0 \\
Subjective health & $-0.107 * * *$ & $-0.121 * * *$ \\
Years of schooling & $-0.003 *$ & $-0.004 * *$ \\
Subjective income & $-0.104 * * *$ & $-0.098^{* * *}$ \\
Never cohabit & $-0.076^{* * *}$ & $-0.064 * * *$ \\
Degree of religiosity & $0.004 *$ & 0.006 \\
Social meetings & $-0.036 * * *$ & $-0.046 * * *$ \\
Social activities & $-0.073 * * *$ & $-0.090^{* * *}$ \\
Marital status & & \\
$\quad$ Divorced/separated & 0.023 & 0.003 \\
$\quad$ Married & $-0.411^{*} * *$ & $-0.471 * * *$ \\
$\quad$ Widowed & $0.229 * * *$ & $0.206 * * *$ \\
\hline
\end{tabular}

(continued) 
Table 3.

Coefficients of Hierarchical Models of Loneliness in Old Age, by Age (Continued)

\begin{tabular}{lll}
\hline Variable & $<65$ & $<75$ \\
\hline Country Characteristics & $0.394 * * *$ & $0.540 * * *$ \\
$\quad$ Mean of loneliness & 0.401 & $0.819 *$ \\
$\quad$ HDI & $2.688^{* * * *}$ & -0.022 \\
Intercept & & \\
Variance Components & $-3.172^{* * *}$ & $-3.314 * * *$ \\
Country variance & $-0.332 * * *$ & $-0.275^{* * *}$ \\
Individual variance & 35926 & 14650 \\
$\mathrm{~N}$ & & \\
\hline
\end{tabular}

$* \mathrm{P}<.1 * * \mathrm{P}<.05 * * * \mathrm{P}<.01$

Source: Own elaboration on European Social Surveys (2006, 2010, 2012, and 2014 waves where the variable of loneliness is available).

Note: additional covariate included in model but not shown here is Year of Survey.

${ }^{a}$ Omitted category: Never-married.

Analyzing the data shows that widowed or divorced/separated are the least happy and most lonely in comparison to both married and never-married. Widowed and divorced men feel 0.8 and 0.5 points lonelier, respectively, than married men on a 1-4 point scale, while the never-married men feel 0.45 points lonelier. Among women, these numbers stand at 0.6 and 0.4 points for the widowed and divorced versus 0.35 for the never-married. These findings are in line with the theory that the never-married have an advantage in their old age compared to other marital statuses, besides those married, since they become accustomed not to use marriage as a form of self-validation, and develop habits that suit their social situation (Gerstel \& Sarkisian, 2006; Gubrium, 1975; Pudrovska et al., 2006; Rubinstein, 1987).

Another notable trend in the hierarchical models is the particularly heavy penalty that the widowed pay in loneliness. While the never-married fare the best in comparison to the married, widowed are lonelier and less happy than the divorced/separated and the never-married in every measured case. The differences are especially large for widowed men, which may be explained by rarity, or within frameworks of masculinity: it is more usual for a wife to outlive her husband, and as such, widowed men may be particularly 
unprepared for single life, and also part of a smaller demographic with less social support and higher levels of stigma. Indeed, research indicates that women are better equipped to deal with widowhood (Bennett et al., 2003).

Looking at some of the intervening mechanisms, Table 2 demonstrates how socioeconomic factors may come into play. Having higher levels of social capital (as measured by frequency of social meetings and social activities) and higher levels of subjective health or income (both allow for more active life) are associated with lower levels of loneliness, and as such, appear to be in alignment with models of "successful aging" (Rowe \& Kahn, 1997; Strawbridge et al., 2002).

\section{Discussion}

The results show married elders are the happiest and the least lonely on average than all other unmarried elders, in line with previous studies (Waite \& Gallagher, 2000). Thereafter, comes the never-married group. In explaining these results, one should consider previous research that shows that nevermarried individuals have an advantage in their old age compared to other marital statuses because they never used marriage as a form of self-validation, and often develop suitable social capital (Gubrium, 1975). The divorced and widowed, however, are faced with sudden change in their life of losing a partner, and their self-perception and levels of mental health are vulnerable in the face of criticism, prejudices, or social isolation (Rubinstein, 1987). Indeed, it was found that never-married older people show fewer signs of stress, are more likely to enjoy living alone, and report needing less social support than newly-single (Pudrovska et al., 2006).

The study of Band-Winterstein and Manchik-Rimon (2014) might also be helpful in explaining these results. In their conclusion, the authors dismiss the preconception that never-married older singles must be lonely by drawing a clear difference between solitude, isolation, and loneliness. According to their research, solitude for many older singles becomes part of a way of living, and loneliness is addressed by close relationships with extended family and friends. Others (Casper et al., 2016) show that contrary to popular beliefs and understanding, long-term singles place high importance on their familial relationship, and in particular, siblings, with most singles valuing their role as a family member more than their career. 
The benefits of friendship for older singles are also very clear: in the absence of a nuclear family or people to socialize with automatically, friends take an increasingly important role in ensuring their wellbeing (Kislev, 2021a, 2021b). Indeed, Tomás et al. (2014) show that feelings of social support are the most important predictor for life satisfaction in old age. It was also shown that having a social support system decreases levels of anxiety, and simultaneously raises the motivation to lead an active and healthy lifestyle (Haber, 2013). Moreover, while most associate friendships with those created in the same peer groups, older singles are more likely to gain a wide variety of friendships (Hartup \& Stevens, 1997). In particular, older singles are more likely to have friends who are both single and married, as well as friends from different generations, and in particular, of both sexes (Bettini \& Norton, 1991; Weger, 2015).

On the other side, there are many who feel lonely after marriage ends. The reasons include feeling socially isolated after years of devoting oneself to the family, neglecting social networks, or feeling caring for an ill partner without anyone else to lend a hand . As stated above, researchers prefer to divide feelings of loneliness into social and emotional dimensions (Weiss, 1973). This distinction is particularly relevant for older people because social loneliness can be increased from being married over many years (Aartsen \& Jylhä, 2011; Dahlberg \& McKee, 2014; Einolf \& Philbrick, 2014; Gerstel \& Sarkisian, 2006). Finally, the never-married singles are also not burdened with the stigma of suddenly being alone, unlike the older widowed and divorced (Gerstel, 1987).

In this sense, this paper expands on the idea of 'greedy marriage' (Einolf \& Philbrick, 2014; Gerstel \& Sarkisian, 2006) that focuses on the effects of marriage on reducing social capital, meaning that never-married singles are socially better prepared for living alone. However, it is not immediately clear to what extent the repertoire for improving singles' wellbeing is developed as a result of the never-married singles having to adapt to their reality, or whether this is a repertoire that predisposes individuals to singlehood. Indeed, the evidence of selection into marriage (Stutzer \& Frey, 2006) would give reason to investigate selection into singlehood - or in other words, selection out of marriage.

In addition, consider the higher penalty that widowed individuals pay in comparison to divorced individuals. The reason might be that they have less years to adjust to their solo lifestyle. On average, widowhood happens at a 
later age than divorce, when there are fewer years to adjust to singlehood. Young divorcees in particular have more time to reconfigure their way of living to suit singlehood, particularly following the mostly transitory effects of divorce (Lucas, 2005). In this sense, the results presented here complement the works of Klinenberg (2012) and Kislev (2019a) that show how singles adapt to living alone.

By better understanding the social, physical, and emotional repertoire of happy long-term singles, it will be possible to make recommendations in two levels. Policy-wise, it could guide lawmakers in creating frameworks for increasing the wellbeing of the fast-growing singles population. Second, such research could provide social workers and counsellors the keys to preventing loneliness both during marriage and in singlehood.

Directions for further enquiry here can be split into three categories. First, and in agreement with other studies on the subject (Haber, 2013; Tomás et al., 2014), the results demonstrate the importance of social capital in decreasing loneliness among older people as is shown in the tables presented here. Given the accounts from other studies (Band-Winterstein \& ManchikRimon, 2014; Kislev, 2019b, 2020b, 2021a; Klinenberg, 2012), it seems that older never-married individuals are especially proficient at exercising their social capital, or that they benefit from it more than the divorced/separated and widowed. If true, and further research is certainly merited, this would help to explain the relative wellbeing of the never-married in comparison with the divorced/separated, and widowed.

Second, this paper provides empirical evidence that justifies further investigation into the mindset that helps singles to live happier lives and be less susceptible to the disadvantages of discrimination, prejudice, and stigma. Older singles face a double social challenge: dealing with the multiple prejudices of being old and single at the same time (Katz, 2005). There is much social criticism about being a long-term single, which entails thinking "something is wrong" about that person (DePaulo, 2011), and there is another set of prejudices against older adults, or ageism, saying they are not as healthy, less funny, and needier (Nelson, 2004). Thus older singles in most cases are at high risk of the consequences of prejudice and stereotyping and experience low levels of social interaction, loneliness, and reduced emotional well-being (Lee \& Masako, 1987). However, the results in this paper point at the plausible ability of long-term never-married singles to improve their self- 
perception by adopting tactics to overcome stereotypes and prejudice within their lives and thus demonstrate the importance of understanding and appreciating these tactics.

The results here also draw attention to the potential of living with others as a solution to loneliness (Gierveld et al., 2012). Different models of coresidency are emerging around the world, such as collective housing for women (Abbit, 2016), living with roommates in middle- an old-age (Gross, 2004), young people moving in with their grandparents (Pinsker, 2017), and more formal arrangements of co-generational living (Shah, 2016). Given that young people are afraid of vulnerability in old age (Parker \& D'Vera Cohn, 2009), and the apparent lack of solutions for the challenges facing the older single, further exploring the alternatives to relationships stands to both assuage fears of growing old alone, and inform future policy programs to promote the wellbeing of older people.

Finally, one should note the selection factor of happier people into marriage (Stutzer \& Frey, 2006) that likely skews the results in this area. Thus, the benign effect of marriage is lower than observed in this paper (the gap is estimated at around 0.3 on a similar scale to that presented here, see: Kislev, 2019a; Stutzer \& Frey, 2006) and requires further research with a special focus on older ages.

\section{Notes}

${ }^{1}$ This study is partly based on: Kislev, Elyakim. 2019. "Chapter 2: Happy Singlehood in Old Age." In Happy Singlehood, 45-78. University of California Press.

\section{References}

Aartsen, M., \& Jylhä, M. (2011). Onset of loneliness in older adults: results of a 28 year prospective study. European Journal of Ageing, 8(1), 31-38.

Abbit, L. (2016). Urban Cohousing the Babayaga Way. Seniors Planet. Retrieved 7/11/2017 from https://seniorplanet.org/senior-housingalternatives-urban-cohousing-the-babayaga-way/ 
95 Aging, Marital Status, and Loneliness - Kislev

Aday, R. H., Kehoe, G. C., \& Farney, L. A. (2006). Impact of Senior Center Friendships on Aging Women Who Live Alone. Journal of women \& aging, 18(1), 57-73. https://doi.org/10.1300/J074v18n01_05

Ardelt, M. (2003). Effects of religion and purpose in life on elders' subjective well-being and attitudes toward death. Journal of religious Gerontology, 14(4), 55-77.

Ayalon, L., Shiovitz-Ezra, S., \& Palgi, Y. (2013). Associations of loneliness in older married men and women. Aging \& Mental Health, 17(1), 33-39. https://doi.org/10.1080/13607863.2012.702725

Band-Winterstein, T., \& Manchik-Rimon, C. (2014). The Experience of Being an Old Never-Married Single: A Life Course Perspective. The International Journal of Aging and Human Development, 78(4), 379-401. https://doi.org/doi:10.2190/AG.78.4.d

Bengtson, V. L., \& Putney, N. M. (2000). Who will care for tomorrow's elderly? Consequences of population aging East and West. Aging in east and west: Families, states, and the elderly, 263-185.

Bennett, K. M., Hughes, G. M., \& Smith, P. T. (2003). "I think a woman can take it": Widowed men's views and experiences of gender differences in bereavement [journal article]. Ageing International, 28(4), 408-424. https://doi.org/10.1007/s12126-003-1012-X

Bettini, L. M., \& Norton, M. L. (1991). The pragmatics of inter generational friendships. Communication Reports, 4(2), 64-72.

Börsch-Supan, A. (2018). Survey of health, ageing and retirement in Europe (SHARE) Wave 6 Version 6) SHARE-ERIC.

Brand, J. E. (2015). The far-reaching impact of job loss and unemployment. Annual Review of Sociology, 41, 359-375.

Casper, W. J., Marquardt, D. J., Roberto, K. J., \& Buss, C. (2016). The Hidden Family Lives of Single Adults Without Dependent Children. In T. D. Allen \& L. T. Eby (Eds.), The Oxford Handbook of Work and Family (pp. 182). Oxford University Press.

Charles, K. K., \& Stephens, J., Melvin. (2004). Job displacement, disability, and divorce. Journal of Labor Economics, 22(2), 489-522.

Cherlin, A. (2009). Marriage, divorce, remarriage. Harvard University Press.

Cheung, A. K.-L., \& Yeung, W.-J. J. (2015). Temporal-spatial patterns of one-person households in China, 1982-2005. Demographic 
Research, S15(44), 1209-1238. http://www.demographicresearch.org/special/15/44/

Clark, A. E., Diener, E., Georgellis, Y., \& Lucas, R. E. (2008). Lags and leads in life satisfaction: A test of the baseline hypothesis. The Economic Journal, 118(529).

Clark, A. E., \& Georgellis, Y. (2013). Back to baseline in Britain: adaptation in the British household panel survey. Economica, 80(319), 496512.

Dahlberg, L., \& McKee, K. J. (2014). Correlates of social and emotional loneliness in older people: evidence from an English community study. Aging \& Mental Health, 18(4), 504-514.

de Jong Gierveld, J., Broese van Groenou, M., Hoogendoorn, A. W., \& Smit, J. H. (2009). Quality of marriages in later life and emotional and social loneliness. Journals of Gerontology Series B: Psychological Sciences and Social Sciences, 64(4), 497-506.

DePaulo, B. (2007). Singled out: How singles are stereotyped, stigmatized, and ignored, and still live happily ever after. Macmillan.

DePaulo, B. (2011). Singlism: What it is, why it matters, and how to stop it. DoubleDoor Books.

DePaulo, B., \& Morris, W. (2006). The unrecognized stereotyping and discrimination against singles. Current Directions in Psychological Science, 15(5), 251-254. https://doi.org/10.1111/j.14678721.2006.00446.x

Drennan, J., Treacy, M., Butler, M., Byrne, A., Fealy, G., Frazer, K., \& Irving, K. (2008). The experience of social and emotional loneliness among older people in Ireland. Ageing \& Society, 28(8), 1113-1132.

Dykstra, P. A., \& Fokkema, T. (2007). Social and emotional loneliness among divorced and married men and women: Comparing the deficit and cognitive perspectives. Basic and applied social psychology, 29(1), 1-12.

Einolf, C. J., \& Philbrick, D. (2014). Generous or Greedy Marriage? A Longitudinal Study of Volunteering and Charitable Giving. Journal of Marriage and Family, 76(3), 573-586.

https://doi.org/10.1111/jomf.12115

Eng, I. (1997). The rise of manufacturing towns: externally driven industrialization and urban development in the Pearl River Delta of 
97 Aging, Marital Status, and Loneliness - Kislev

China. International Journal of Urban and Regional Research, 21(4), 554-568.

Euromonitor. (2013). Downsizing Globally: The Impact of Changing Household Structure on Global Consumer Markets.

Fischlmayr, I. C. (2002). Female self-perception as barrier to international careers? The International Journal of Human Resource Management, 13(5), 773-783.

https://doi.org/10.1080/09585190210125912

Fokkema, T., De Jong Gierveld, J., \& Dykstra, P. A. (2012). Cross-national differences in older adult loneliness. The Journal of Psychology, 146(1-2), 201-228.

Frijters, P., Johnston, D. W., \& Shields, M. A. (2011). Life satisfaction dynamics with quarterly life event data. The Scandinavian Journal of Economics, 113(1), 190-211.

Gatz, M., \& Zarit, S. H. (1999). A good old age: Paradox or possibility. Handbook of theories of aging, 396-416.

Gerstel, N. (1987). Divorce and stigma. Social problems, 34(2), 172-186.

Gerstel, N., \& Sarkisian, N. (2006). Marriage: The Good, the Bad, and the Greedy. Contexts, 5(4), 16-21. https://doi.org/10.1525/ctx.2006.5.4.16

Gierveld, J., Dykstra, P. A., \& Schenk, N. (2012). Living arrangements, intergenerational support types and older adult loneliness in Eastern and Western Europe. Demographic Research, 27(2), 167.

Golini, A., \& Silverstrini, A. (2013). Family change, fathers, and children in Western Europe: a demographic and psychosocial perspective. The Family on the Threshold of the 21st Century: Trends and Implications, 201.

Gross, J. (2004). Older Women Team Up to Face Future Together. The New York Times. Retrieved 3/16/2017 from http://www.nytimes.com/2004/02/27/us/older-women-team-up-toface-future-together.html

Gubrium, J. F. (1975). Being Single in Old Age. The International Journal of Aging and Human Development, 6(1), 29-41. https://doi.org/doi:10.2190/31LW-101Q-0PWX-VV9J

Haber, D. (2013). Health promotion and aging: Practical applications for health professionals. Springer Publishing Company. 
Halmos, P. (2013). Solitude and privacy: A study of social isolation, its causes and therapy. Routledge.

Hartup, W. W., \& Stevens, N. (1997). Friendships and adaptation in the life course. Psychological Bulletin, 121(3), 355.

HDI. (2016, October 2013). Human Development Index. Human

Development Report Office, the United Nation.

http://hdr.undp.org/en/statistics/

Holwerda, T. J., Deeg, D. J. H., Beekman, A. T. F., van Tilburg, T. G., Stek, M. L., Jonker, C., \& Schoevers, R. A. (2012). Feelings of loneliness, but not social isolation, predict dementia onset: results from the Amsterdam Study of the Elderly (AMSTEL). Journal of Neurology, Neurosurgery \& Psychiatry. https://doi.org/10.1136/jnnp-2012302755

John, P. D. S., Tyas, S. L., Griffith, L. E., \& Menec, V. (2017). The cumulative effect of frailty and cognition on mortality-results of a prospective cohort study. International psychogeriatrics, 29(4), 535543.

Kalmijn, M., \& van Groenou, M. B. (2005). Differential effects of divorce on social integration. Journal of social and personal relationships, 22(4), 455-476.

Katz, S. (2005). Cultural aging: Life course, lifestyle, and senior worlds. Broadview Press.

Kay, D., Beamish, P., \& Roth, M. (1964). Old age mental disorders in Newcastle upon Tyne. The British Journal of Psychiatry, 110(468), 668-682.

Kislev, E. (2018). Happiness, Post-materialist Values, and the Unmarried. Journal of happiness Studies, 19(8), 2243-2265.

Kislev, E. (2019a). Happy Singlehood: The Rising Acceptance and Celebration of Solo Living. Berkeley: University of California Press.

Kislev, E. (2019b). Social Capital, Happiness, and the Unmarried: a Multilevel Analysis of 32 European Countries. Applied Research in Quality of Life, 15(5), 1475-1492.

Kislev, E. (2020a). Does Marriage Really Improve Sexual Satisfaction? Evidence From the Pairfam Data Set. The Journal of Sex Research, 57(4), 470-481. 
99 Aging, Marital Status, and Loneliness - Kislev

Kislev, E. (2020b). How do relationship desire and sociability relate to each other among singles? Longitudinal analysis of the Pairfam survey. Journal of social and personal relationships.

Kislev, E. (2021a). Reduced relationship desire is associated with better life satisfaction for singles in Germany: An analysis of pairfam data. Journal of social and personal relationships.

Kislev, E. (2021b). The Sexual Activity and Sexual Satisfaction of Singles in the Second Demographic Transition. Sexuality Research and Social Policy, 18, 726-738.

Klinenberg, E. (2012). Going solo: The extraordinary rise and surprising appeal of living alone. Penguin.

Kunz, P. R., \& Albrecht, S. L. (1977). Religion, marital happiness, and divorce. International journal of sociology of the family, 7(2), 227232.

Lavee, Y., \& Katz, R. (2003). The family in Israel: Between tradition and modernity. Marriage \& Family Review, 35(1-2), 193-217.

Lawton, M. P., \& Lawrence, R. H. (1994). Assessing health. Annual review of gerontology and geriatrics, 14(1), 23-56.

Lee, G. R., \& Masako, I.-K. (1987). Social Interaction, Loneliness, and Emotional Well-Being among the Elderly. Research on Aging, 9(4), 459-482. https://doi.org/doi:10.1177/0164027587094001

Lopata, H. Z. (1969). Loneliness: Forms and components. Social problems, 17(2), 248-262.

Lucas, R. E. (2005). Time does not heal all wounds: A longitudinal study of reaction and adaptation to divorce. Psychological science, 16(12), 945-950.

Lucas, R. E., Clark, A. E., Georgellis, Y., \& Diener, E. (2003). Reexamining adaptation and the set point model of happiness: reactions to changes in marital status. Journal of personality and social psychology, 84(3), 527-539. https://doi.org/10.1037/00223514.84.3.527

McKenzie, J. A. (2013). Disabled people in rural South Africa talk about sexuality. Culture, health \& sexuality, 15(3), 372-386.

Meece, J. L., Glienke, B. B., \& Burg, S. (2006). Gender and motivation. Journal of School Psychology, 44(5), 351-373. https://doi.org/10.1016/j.jsp.2006.04.004 
Morris, W., Sinclair, S., \& DePaulo, B. (2007). No shelter for singles: The perceived legitimacy of marital status discrimination. Group Processes \& Intergroup Relations, 10(4), 457-470. https://doi.org/10.1177/1368430207081535

Musick, K., \& Bumpass, L. (2012). Reexamining the case for marriage: Union formation and changes in well-being. Journal of Marriage and Family, 74(1), 1-18.

Nelson, T. D. (2004). Ageism: Stereotyping and prejudice against older persons. MIT press.

Newall, N. E., Chipperfield, J. G., Clifton, R. A., Perry, R. P., Swift, A. U., \& Ruthig, J. C. (2009). Causal beliefs, social participation, and loneliness among older adults: A longitudinal study. Journal of social and personal relationships, 26(2-3), 273-290.

Parker, K., \& D'Vera Cohn, S. W. (2009). Growing Old in America: Expectations vs. Reality. Pew Research Center, Social \& Demographic Trends Project.

Perlman, D., \& Peplau, L. A. (1981). Toward a social psychology of loneliness. Personal relationships, 3, 31-56.

Pinquart, M., \& Sörensen, S. (2003). Risk factors for loneliness in adulthood and old age--a meta-analysis. Nova Science Publishers.

Pinsker, B. (2017). Your Money: Creative caregiving solutions for the 'sandwich generation'. Rauters. Retrieved 7/18/2017 from http://www.reuters.com/article/us-money-retirement-sandwichgenidUSKBN18R2TT

Post, F. (1951). Mental Breakdown in Old Age. British medical journal, l(4704), 436.

Powdthavee, N. (2009). What happens to people before and after disability? Focusing effects, lead effects, and adaptation in different areas of life. Social Science \& Medicine, 69(12), 1834-1844.

Pudrovska, T., Schieman, S., \& Carr, D. (2006). Strains of Singlehood in Later Life: Do Race and Gender Matter? The Journals of Gerontology: Series B, 61(6), S315-S322. https://doi.org/10.1093/geronb/61.6.S315

Rosenkoetter, M. M., \& Garris, J. M. (1998). Psychosocial changes following retirement. Journal of Advanced Nursing, 27(5), 966-976. https://doi.org/10.1046/j.1365-2648.1998.00569.x 
101 Aging, Marital Status, and Loneliness - Kislev

Rowe, J. W., \& Kahn, R. L. (1997). Successful aging. The gerontologist, 37(4), 433-440.

Rubinstein, R. L. (1987). Never married elderly as a social type: Reevaluating some images. The gerontologist, 27(1), 108-113.

Sargent-Cox, K. A., Anstey, K. J., \& Luszcz, M. A. (2010). Patterns of longitudinal change in older adults' self-rated health: The effect of the point of reference. Health Psychology, 29(2), 143.

Scharf, T., Phillipson, C., \& Smith, A. E. (2005). Social exclusion of older people in deprived urban communities of England. European Journal of Ageing, 2(2), 76-87.

Shah, Y. (2016). 'Airbnb For Seniors' Helps Link Travelers With LikeMinded Hosts. Huffington Post. Retrieved 6/6/2017 from http://www.huffingtonpost.com/entry/airbnb-for-seniors-helps-linktravelers-with-like-minded-hosts_us_57487aa1e4b0dacf7ad4c130

Singleton, P. (2012). Insult to injury disability, earnings, and divorce. Journal of Human Resources, 47(4), 972-990.

Soons, J. P., Liefbroer, A. C., \& Kalmijn, M. (2009). The long-term consequences of relationship formation for subjective well-being. Journal of Marriage and Family, 71(5), 1254-1270.

Sorkin, D., Rook, K. S., \& Lu, J. L. (2002). Loneliness, lack of emotional support, lack of companionship, and the likelihood of having a heart condition in an elderly sample [journal article]. Annals of Behavioral Medicine, 24(4), 290-298.

https://doi.org/10.1207/s15324796abm2404_05

Stack, S. (1998). Marriage, family and loneliness: A cross-national study. Sociological Perspectives, 41(2), 415-432.

Strawbridge, W. J., Wallhagen, M. I., \& Cohen, R. D. (2002). Successful aging and well-being self-rated compared with Rowe and Kahn. The gerontologist, 42(6), 727-733. https://doi.org/10.1093/geront/42.6.725

Stutzer, A., \& Frey, B. S. (2006). Does marriage make people happy, or do happy people get married? The Journal of Socio-Economics, 35(2), 326-347.

https://doi.org/http://dx.doi.org/10.1016/j.socec.2005.11.043

Tomás, J. M., Sancho, P., Gutiérrez, M., \& Galiana, L. (2014). Predicting Life Satisfaction in the Oldest-Old: A Moderator Effects Study 
[journal article]. Social Indicators Research, 117(2), 601-613. https://doi.org/10.1007/s11205-013-0357-0

Victor, C., Scambler, S., Bond, J., \& Bowling, A. (2000). Being alone in later life: Loneliness, social isolation and living alone. Reviews in Clinical Gerontology, 10(4), 407-417.

Victor, C. R., \& Yang, K. (2012). The Prevalence of Loneliness Among Adults: A Case Study of the United Kingdom. The Journal of Psychology, 146(1-2), 85-104. https://doi.org/10.1080/00223980.2011.613875

Vitali, A. (2010). Regional differences in young Spaniards' living arrangement decisions: A multilevel approach. Advances in life course research, 15(2), 97-108.

Waite, L., \& Gallagher, M. (2000). The case for marriage: Why married people are happier, healthier and better off financially. New York: Random House

Walsh, F. (1996). The concept of family resilience: Crisis and challenge. Family process, 35(3), 261-281.

Wang, W., \& Parker, K. C. (2014). Record share of Americans have never married: As values, economics and gender patterns change. Pew Research Center.

Weger, H. (2015). Cross-Sex Friendships. In The International Encyclopedia of Interpersonal Communication. John Wiley \& Sons, Inc. https://doi.org/10.1002/9781118540190.wbeic131

Weis Farone, D., Fitzpatrick, T. R., \& Tran, T. V. (2005). Use of senior centers as a moderator of stress-related distress among latino elders. Journal of Gerontological Social Work, 46(1), 65-83. https://doi.org/10.1300/J083v46n01_05

Weiss, R. S. 1973. the Experience of Emotional and Social Isolation. Cambridge, Mass: MIT Press

Wenger, G. C. (1992). Morale in old age: a review of the evidence. International Journal of Geriatric Psychiatry, 7(10), 699-708.

Wilson, F., Kickul, J., \& Marlino, D. (2007). Gender, entrepreneurial selfefficacy, and entrepreneurial career intentions: implications for entrepreneurship education. Entrepreneurship Theory and Practice, 31(3), 387-406.

Wilson, J. Q. (2002). The marriage problem: How our culture has weakened families. JSTOR. 
103 Aging, Marital Status, and Loneliness - Kislev

Yang, K., \& Victor, C. R. (2011). Age and loneliness in 25 European nations. Ageing and Society, 31(8), 1368-1388.

https://doi.org/10.1017/S0144686X1000139X

Zeldin, A. L., Britner, S. L., \& Pajares, F. (2008). A comparative study of the self-efficacy beliefs of successful men and women in mathematics, science, and technology careers. Journal of Research in Science Teaching, 45(9), 1036-1058.

Zimmermann, A. C., \& Easterlin, R. A. (2006). Happily ever after?

Cohabitation, marriage, divorce, and happiness in Germany. Population and Development Review, 32(3), 511-528. https://doi.org/10.1111/j.1728-4457.2006.00135.x

Elyakim Kislev. Assistant Professor at the Hebrew University of Jerusalem. The Federmann School of Public Policy and Government, Campus Mount Scopus Jerusalem.

ORCID: https://orcid.org/ 0000-0001-5587-2031

Contact Address: elyakim.kislev@mail.huji.ac.il 